\title{
ПСИХИАТРИЯ
}

UDC 616-021.3;616.89-02-07

\section{Future directions in genome-wide association studies of schizophrenia spectrum disorders}

\author{
N. V.Zakharova, ${ }^{1,2}$ I.I.Nizamutdinov ${ }^{3}$, V. V.Musatova ${ }^{3}$, V. V.Ilinsky ${ }^{3,4}$, \\ A. Yu. Morozova ${ }^{2,5}$, M. O. Bocharova ${ }^{6}$, A. M. Reznik 7 , G. P. Kostyuk ${ }^{2}$ \\ ${ }^{1}$ Pirogov Russian National Research Medical University, 1, Ostrovitianov ul., Moscow, 117997, Russian \\ Federation \\ ${ }^{2}$ Psychiatric Clinical Hospital 1 named after N. A. Alekseev, 2, Zagorodnoe sh., Moscow, 115191, Russian \\ Federation \\ ${ }^{3}$ Genotek Ltd., 17, build 1, Nastavnicheskii per., Moscow, 105120, Russian Federation \\ ${ }^{4}$ Institute of Biomedical Chemistry, 10, Pogodinskaya street, Moscow, 119121, Russian Federation \\ ${ }^{5}$ V.Serbsky National Medical Research Center for Psychiatry and Narcology, 23, Kropotkinskii per., \\ Moscow, 119991, Russian Federation \\ ${ }^{6}$ King's College London, 16, De Crespigny Park, London, SE5 8AF, UK \\ ${ }^{7}$ Moscow State University of Food Production, 11, Volokolamskoe sh., Moscow, 125080, Russian \\ Federation
}

For citation: Zakharova N.V., Nizamutdinov I.I., Musatova V.V., Ilinsky V. V., Morozova A. Yu., Bocharova M.O., Reznik A.M., Kostyuk G.P. Future directions in genome-wide association studies of schizophrenia spectrum disorders. Vestnik of Saint Petersburg University. Medicine, 2018, vol.13, issue 1, pp. 72-82. https://doi.org/10.21638/11701/spbu11.2018.107

The rapid expansion of diagnostic technologies in general and of the genome-wide association studies method in particular brings us closer to the understanding of the etiopathogenetic fundamentals of endogenous mental disorders. The amount of accumulated experience in genome-wide association studies allows one to assess the importance of specific genetic markers in the development of the diseases of interest. The introduction of screening systems and the assessment of disease prognosis is yet to be implemented, due to conceptual and methodological contradictions. The present review aims at analyzing the current progress in the field of genetic studies of schizophrenia spectrum disorders. The prospects and limitations of existing methods and the obstacles to the efficient translational application of the achievements of GWAS and candidate gene studies are discussed. Along with the still poor understanding of the etiology and pathogenesis of schizophrenia spectrum disorders, such issues as the ongoing debate regarding the correct classification, as well as the large degree of symptom heterogeneity within this group of conditions, remain a cornerstone in biological research. A more accurate approach to phenotyping, including the application of deep

() Санкт-Петербургский государственный университет, 2018 
phenotyping techniques, is required to form more homogenous samples for future genomewide association and candidate gene studies of schizophrenia spectrum disorders.

Keywords: schizophrenia, genetic marker, single nucleotide polymorphism, genome-wide association study, phenotyping.

\section{Introduction}

The biopsychosocial paradigm is the basis of the modern understanding of endogenous mental disorders. Notably, all three components of this concept seem to be equally valued. In the social aspect, the burden of schizophrenia spectrum disorders is estimated to be up to $0.5 \%$ of country's GDP [1]. The prevalence of this group of disorders appears to be relatively stable over time and varies insignificantly by region $(1.45 \%, 0.5 \%, 1.6 \%$ respectively) [2]. According to epidemiological data across Russian Federation, schizophrenia cases constitute $16 \%$ of all the individuals suffering from mental diseases and 40$50 \%$ of inpatients. The morbidity in Russia has been estimated as 6.5 per 100 thousands per year or about 9.5 thousand first-time registered cases annually. The number of people receiving psychiatric treatment is 467.1 thousand or 319.3 per 100 thousand [3]. Disability is observed in about $60 \%$ of patients diagnosed with schizophrenia, while $90 \%$ have unstable labor force adaptation. The socio-economic burden of schizophrenia (according to the 2009 calculations) in Russia amounts to 196.7 billion rubles per year, $90 \%$ of which is cost of accommodation of patients in clinics and medical facilities [1].

Despite the high socio-economic costs of schizophrenia spectrum disorders, efficient treatment for this group of disorders is still lacking. It is economically important that the medication for the treatment of schizophrenia are included in the index of vital and essential drugs [4] and therefore are part of the government budget expenses. It is worth noting that the etiotropic treatment for the schizophrenia spectrum disorders has not been developed and an introduction of anti-psychotic drugs into the clinical practice has not hastened a solution for the full curability problem. Moreover, large-scale studies of the efficiency of anti-psychotic drugs have shown high rates of treatment resistance $[5 ; 6]$.

The etiology of the schizophrenia spectrum disorders is not well established yet. Several hypotheses of the etiogenesis of these diseases exist simultaneously. The majority of those can be narrowed down to the imbalance of neuromediators in the nervous system, i.e. dopamine, serotonin, noradrenaline and GABA [7-9]. Despite the lack of full understanding of the etiology and pathogenesis of schizophrenia spectrum disorders, the multifactorial nature of these disorders remains the most widely accepted concept, i.e. that taking account of the contribution of genetic and environmental factors into disease risk. A meta-analysis of twelve twin studies has demonstrated high heritability of schizophrenia spectrum disorders (estimated at $81 \%$ ) [10], which supports the dominant position of genetic factors in determining the risk for this group of disorders. At the same time, so far, there have been no valid techniques allowing to assess the risk of developing schizophrenia in an individual by means of genetic analysis. This problem can be most probably explained by the following range of reasons: the lack of unified methodology of genetic studies, the lack of unified criteria for diagnosis, and the pathogenetic heterogeneity of this group of disorders.

This review aims at analyzing the existing conceptual and methodological problems which stand in the way of the implementation of genetic testing into the diagnosis of schizophrenia, as well as possible solutions to these problems. 


\section{Methodological issues in genetic studies of schizophrenia spectrum disorders}

No monogenic forms of schizophrenia spectrum disorders have been described to date [11]. The input of genetic factors into the development of these disorders is attributable to a multitude of genetic markers, each of those potentially increasing the risk of disease. Around 8000 polymorphisms have been associated with schizophrenia spectrum disorders in case-control studies [12]. However, it is too early to draw definite conclusions concerning the association of all these genetic markers with the risk of disease. First, the majority of associations have been implicated in studies with limited sample size and in specific populations. Second, quite a few of the findings have not been replicated in different samples.

The active implementation of Genome-wide association studies (GWAS) has enabled the analysis of a large number of genetic markers in large-scale patient and control samples. However, the markers identified using genome-wide studies can only explain up to $25 \%$ of the genetic variance in morbidity risk [13]. Besides, a significant number of these genetic markers lie outside candidate-gene loci, and their implication for disease pathogenesis is not entirely clear. An important feature of GWAS is stringent criteria of significance for the associated polymorphisms: an association is only considered significant if p-value is smaller than $5^{\star} 10^{-8}$ [14]. Such stringent selection criteria inevitably lead to false-negative results.

It is also of note that neither GWAS nor candidate-gene studies take into account the possible contribution of chromosome mutations: genomic and autosomal aneuploidy, gene inversion and conversion, as well as copy number variation. At the same time, chromosome 1 and 18 mosaic aneuploidy have been implicated as associated with schizophrenia in a few postmortem cases $[15 ; 16]$. Also 22q11DS syndrome, characterized, in the majority of cases, by an inborn loss of 3 million base pairs of the long arm of chromosome 22 (22q11.2), has been accepted as a model of ultra-high risk of schizophrenic psychosis for research into environmental predictors of the disease [17].

Populational differences also represent a significant issue for valid determination of genetic predisposition to schizophrenia spectrum disorders. Some genetic markers associated with increased risk of schizophrenia in certain populations, do not demonstrate a similar asociation in other populations [18]. This can be attributed, in the first place, to the difference in prevalence of genetic markers across various populations subject to the conditions of their habitat, e.g. the polymorphism $r s 1042522$, which regulates body temperature and enables representatives of some asian nations to withstand cold winters [19]. Some authors believe that genetic polymorphisms associated with risk of schizophrenia can also be subject to natural selection - e.g. polymorphisms of the genes CREB1, SLC39A8, ZNF323 и SLC6A4 [20-22].

Another possible reason of the populational differences in the prevalence of schizophrenia-associated polymorphisms in the population is the presence in the history of some nations of the so-called «bottlenecks»: time periods when a significant part of the population perished, and only the remaining minority determined the genotype of the ancestry [23]. Therefore, the populational affiliation of the individuals is an important parameter which has to be accounted for in studies dedicated to the search of genetic markers associated with schizophrenia. 
Thus, the methodological issues in the search for genetic factors determining risk of schizophrenia spectrum disorders can be narrowed down to the following:

1. The presence of a wide range of candidate genes whose association with schizophrenia has been implicated in local populations and has not been consistently replicated in other samples.

2. Stringent criteria imposed by GWAS to the selection of genetic markers associated with conditions of interest.

3. The lack of account of populational differences in the frequency of alleles serving as genetic markers in schizophrenia spectrum disorders.

\section{Issues related to the consistency of diagnostic criteria for schizophrenia spectrum disorders}

A crucial issue in the interpretation of the results of genetic studies is the fundamental controversy regarding the clinical criteria of the diagnosis of schizophrenia which still exists among research groups. The justification of the inclusion of symptoms and syndromes into one nosological form of mental disorders or the other has been a matter of ongoing debate in clinical psychiatry. The diagnosis is made according to one of the accepted international classifications - ICD-10 [24] or DSM-5 [25]. The inclusion criteria of the majority of studies focusing on the identification of genetic factors associated with schizophrenia require that the patient's condition matches F2 section of ICD-10, while the specification of those conditions is missing. At the same time, this section includes a wide spectrum of discreet disorders, differing significantly in the characteristics of their clinical course and presentation. An illustrative example of the controversy between the classifications is the putative position of catatonic symptoms. While the ICD-10 F2 section includes the category of catatonic schizophrenia (F20.2), in DSM-5, its symptoms constitute a separate dimension which is viewed as not specific to schizophrenia [26]. It has been estimated the the pathogenesis of catatonia lies in specific neurobiological and neuroimmunological mechanisms different from those in other forms of mental disorders [27;28]. Consequently, one can assume that these notions could also be true for a wide spectrum of affective (depressive and manic) disorders which fall under F 20.4 - post-schizophrenic depression - and F25 - schizoaffective disorder - categories. Conditions matching the above mentioned ICD codes are characterised by the prevalence in their clinical presentation of mood disorders, while schizophrenia symptoms become secondary and fade into insignificance. A different diagnostic dilemma consists in the fact that Schneider's first rank symptoms such as voice echo, thought detachment, and intra-proective hearing perceptional deception, which are obligatory for paranoid schizophrenia (F20) are not present in simple schizophrenia and pseudo-neurotic and pseudopsychopathic latent schizophrenia (coded as F21.3 and 21.4, respectively). It would be reasonable to assume that the development of the above mentioned clinical symptoms is determined by different underlying pathophysiological abnormalities. Therefore, orienting on ID criteria alone in patient enrollment can lead to the formation of a highly heterogenous sample.

The data obtained in fundamental (non-clinical) studies in the field on neurosciences confirm the impossibility to directly match ICD and DSM-defined diagnoses with laboratory data [29]. Against the background of the absence of direct biological associations between various clinical subtypes manifesting with psychotic symptoms as defined by ICD 
or DSM criteria, suggestions to reassess Kraepelin's paradigm appear quite reasonable [30; 31].

In order to overcome the conceptional gap between the widely accepted classifications, NIMH (USA) initiated the introduction of the RDoC project which represents a fundamentally new approach to research into psychopathology and which suggests the shifting away from traditional nosologic categories [32]. The basic objective of this project lies in the search of etiopathogenetic predictors of mental disorders in order to establish novel therapeutic methods. To do so, authors have established a matrix of domains (basic psychopathological manifestations) which includes positive, negative, cognitive disturbances, a set of disturbances manifesting in the social sphere, as well as activating and modulating symptom sets. It has been suggested to trace the whole chain of processes for each domain to construct - starting with behavioral manifestations and down to genetic level - for each of the domains. However, at present, the project is still at initial stages of implementation [29].

Based on provided data, the following issues related to the consistency of diagnostic criteria for schizophrenia spectrum disorders, could be outlined:

1. The absence of a unitary set of criteria for the diagnosis of schizophrenia based on the constellation of symptoms.

2. The controversy that still exists between widely accepted disease classifications with regard to the nosological differences of various mental disorders

3. The lack of account of the heterogeneity of the etiopathogenesis of schizophrenia spectrum disorders and comorbid mental pathology in genetic studies.

\section{Discussion}

The inconsistency of the currently existing approach to the search for genetic markers of schizophrenia spectrum disorders - i.e. the one taking little account of subgrouping these disorders or of the pathophysiological processes which may be specific to distinct disorders, - has been supported by the data indicating the association of different clinical manifestations of the disorders with particular genetic markers [13]. For instance, a few studies have associated their genetic findings only with certain forms of schizophrenia [33], while other studies, conversely, linked these markers to varying disorders [34].

Studies involving a detailed description of clinical characteristics and the specification of clinical and genetic associations are few and are largely focused on the studies of candidate genes determining particular symptoms. For example, the 5-HTTLPR polymorphism of the SLC6A4 gene has been associated with impaired mimic emotion recognition in schizophrenia, but not with cognitive disturbances, the severity of positive symptoms or premorbid personality features [35]. The polymorphisms of the BDNF gene and their association with symptoms have also been thoroughly studied: the 66Met allele of BDNF has been associated with thought insertion, passivity delusions and verbal hallucinations [36]. Besides, it has been estimated that BDNF gene polymorphisms are associated not only with schizophrenia, but also with a range of other disorders characterized by similar symptoms $[37 ; 38]$.

Apart from that, an illustration of the possible reasons for lack of clarity in the interpretation of GWAS results, as mentioned before, is the attribution of catatonic syndrome to schizophrenia spectrum disorders only, with little account of the course and 
stage of disease in which patients manifesting with catatonic phenomena were assessed. It has been shown that the neuronal pathways involved in the development of psychomotor disturbances typical of acute catatonia are different from those determining paranoid or pseudoneurotic symptoms in other forms of schizophrenia spectrum disorders [39]. Special psychomotor phenomena constituting the catatonic syndrome may represent the interaction of orbitofrontal cortex with dorsolateral prefrontal cortex and the premotor loop, with specific alterations in the neurotransmitter components: decreased GABA-A receptor activity (in the orbitofrontal cortex), decreased D2 activity in corpus striatum, alterations in NMDA glutamatergic system (in the parietal cortex) and elevated 5HT-1A receptor activity [40].

Data regarding the clinical significance of the identification of genetic markers of catatonia is limited, and its interpretation is a matter of debate. Zhilyaeva et al. [41] assessed 150 patients presenting with signs of catatonia using PANSS, SANS and CDSS scales. The conceptual approach to the evaluation of mental state in such a limited set of psychometric tools in this work represented the "pyramidical model of schizophrenia" [42], according to which, the catatonic syndrome, as a form of schizophrenia, lies at a nominal edge of a pyramid formed by negative and positive poles of the PANSS subscales (including negative, positive, cognitive disturbances, manifestations of depression and agitation). The results of the study have demonstrated a robust difference in the severity of catatonic symptoms as assessed with PANSS: in the study group (MTHFR $677 C>$ T carriers), catatonic symptoms were significantly more severe than in the comparison group (MTHFR 677CC carriers). Authors conclude that the genetic testing for the described marker could be used in the diagnosis of the risk of catatonic syndrome as a predictor of unfavorable course of schizophrenia. However, other studies have indicated a relatively favorable course of schizophrenia even after several catatonic attacks, i.e. a steady remission and the maintenance of social functioning [43]. Therefore, the evaluation of the significance of particular polymorphisms remains a matter of future studies, which would require account $f$ the maximum possible number of mental phenomena.

\section{Conclusion}

The technological progress of laboratory diagnostics has sufficiently accelerated the understanding of causes and mechanisms of mental disorders, and first of all, schizophrenia spectrum disorders. To date, it has been estimated that the development of these disorders is subject to several brain systems operating at the level of neuron formation [44], neurotransmitter system functioning, cell oxidation and metabolism, and ion channel functioning. The direct involvement of the immune system in the pathogenesis of schizophrenia has been demonstrated as well [45]. All these abnormalities are «coded» in more than 8000 genes. Genetic markers found in genome-wide studies can only explain a small percent of genetic causes of schizophrenia spectrum disorders. The problems of practical implementation of data concerning the genetic foundation of schizophrenia spectrum disorders may lie in the lack of current understanding of the etiology and pathogenesis of these disorders and of a unified and generally accepted classification and diagnostic tools, as well as in the marked heterogeneity of symptoms. A possible solution to the above mentioned issues could be a genetic study of patients diagnosed with schizophrenia with account of phenotypical separation to form clinically homogenous samples. In studying 
genetic markers, it is reasonable to rely upon both GWAS data since they have yielded genetic marker data, and the analysis of polymorphisms in candidate genes whose products are involved in disease pathogenesis.

Deep phenotyping has proved to be of crucial importance in performing GWAS of a number of other multifactorial disorders. The division of patient samples into several clinical subtypes allows to determine polymorphisms directly involved in the pathogenesis of a certain disease. For instance, a genome-wide study of patients suffering from ischemic stroke with account of disease subtypes has yielded genetic markers in the PITX2 and ZFHX3 genes associated with cardioembolic stroke alone [46]. Earlier, these genes had been associated with risk of atrial fibrillation (AF) [47; 48]. While AF leads to haemodynamic abnormalities and thromboembolic complications, mentioned polymorphisms were not associated with minor or major vessel disorders and did not reach full-genome significance $\left(p<5^{\star} 10^{-8}\right)$ in the analysis of the association with ischemic stroke without disease subtyping.

The phenotyping of patients suffering from schizophrenia spectrum disorders is possible with the use of common international psychometric tools allowing for a thorough description of clinical presentation and course of disease with further formation of discrete subgroups based on the severity of impairment of various areas of mental functions (perception, reasoning, psychomotor function, mood, cognitive function etc.), disease duration, the presence of comorbid disorders, ethnic and social characteristics of subjects, and the effect of environmental factors.

\section{References}

1. Gurovich I., Lyubov E. The economic burden of schizophrenia in Russia. European Psychiatry, 2002, vol. 17, p. 149.

2. Goldner E. M., Hsu L., Waraich P., Somers J.M. Prevalence and incidence studies of schizophrenic disorders: a systematic review of the literature. Can. J. Psychiatry, 2002, vol. 47, pp. 833-843.

3. Russia' 2015. Statistical pocketbook. Moscow, 2015. 62 p.

4. Perechen' zhiznenno neobkhodimykh $i$ vazhneishikh lekarstvennykh preparatov dlia meditsinskogo primeneniia na 2017 god [Vital and Essential Drugs List in 2017]. Available at: http://static.government. ru/media/files/CCfPFzQvKjOEoRT5z9SeobntD7hnmX2t.pdf (accessed: 10.04.17). (In Russian)

5. Lieberman J. A., Stroup T.S., McEvoy J. P., Swartz M.S., Rosenheck R.A., Perkins D. O., Keefe R.S., Davis S.M., Davis C.E., Lebowitz B. D., Severe J., Hsiao J.K. Effectiveness of antipsychotic drugs in patients with chronic schizophrenia. N. Engl. J. Med., 2005, vol. 353, no. 12, pp. 1209-1223.

6. McEvoy J.P. An overview of the Clinical Antipsychotic Trials of Intervention Effectiveness (CATIE) study. CNS Spectr., 2006, vol. 11, no. 7 (Suppl. 7), pp.4-8.

7. Krystal J.H., D'Souza D.C. D-serine and the therapeutic challenge posed by the N-methyl-D-aspartate antagonist model of schizophrenia. Biol. Psychiatry, 1998, vol. 44, pp. 1075-1076.

8. Duncan G. E., Zorn S., Lieberman J. A. Mechanisms of typical and atypical antipsychotic drug action in relation to dopamine and NMDA receptor hypofunction hypotheses of schizophrenia. Mol. Psychiatry, 1999, vol. 4, pp. 418-428.

9. Richelson E. Neuroleptic binding to human brain receptors: relation to clinical effects. Ann. N. Y. Acad. Sci., 1988, vol. 537, pp. 435-442.

10. Sullivan P.F., Kendler K.S., Neale M.C. Schizophrenia as a complex trait: evidence from a metaanalysis of twin studies. Arch. Gen. Psychiatry, 2003, vol. 60, pp. 1187-1192.

11. Reznik A.M., Kostiuk G.P., Khannanova A.N. Problemy predposylok shizofrenii po dannym molekuliarno-geneticheskikh issledovanii [Vulnerability for schizophrenia on the basis of molecular genetics investigations]. Social and Clinical Psychiatry, 2016, vol.26, no. 3, pp. 101-108. (In Russian)

12. Allen N.C., Bagade S., McQueen M.B., Ioannidis J.P., Kavvoura F.K., Khoury M.J., Tanzi R.E., Bertram L. Systematic Meta-Analyses and Field Synopsis of Genetic Association Studies in Schizophrenia: The SzGene Database. Nat Genet, 2008, vol. 40, no. 7, pp. 827-834. 
13. Arnedo J., Svrakic D.M., Del Val C., Romero-Zaliz R., Hernández-Cuervo H. Molecular Genetics of Schizophrenia Consortium, et al. Uncovering the hidden risk architecture of the schizophrenias: confirmation in three independent genome-wide association studies. Am. J. Psychiatry, 2015, vol.172, pp. 139-153.

14. Pearson T. A., Manolio T. A. How to interpret a genome-wide association study. JAMA, 2008, vol.299, pp. 1335-1344.

15. Tiganov A.S., Iurov Iu.B., Vorsanova S. G., Iurov I. Iu. Nestabil'nost' genoma golovnogo mozga: etiologiia, patogenez i novye biologicheskie markery psikhicheskikh boleznei [Genomic instability in the brain: etiology, pathogenesis and new biological markers of psychiatric disorders]. Vestnik Rossiiskoi akademii meditsinskikh nauk [Annals of the Russian academy of medical sciences], 2012, vol. 67, no. 9, pp. 45-53. (In Russian)

16. Iurov I. Iu., Vorsanova S. G., Iurov Iu. B. Genomnye i khromosomnye bolezni tsentral'noi nervnoi sistemy: molekuliarnye i tsitogeneticheskie aspekty [Genome and chromosome diseases of central nervous system]. Moscow, Medpraktika-M Publ., 2014. 384 p. (In Russian)

17. Schneider M., Armando M., Pontillo M., Vicari S., Debbané M., Schultze-Lutter F., Eliez S. Ultra high risk status and transition to psychosis in 22q11.2 deletion syndrome. World Psychiatry, 2016, vol.15, pp. $259-265$.

18. Liu J., Li M., Su B. GWAS-identified schizophrenia risk SNPs at TSPAN18 are highly diverged between Europeans and East Asians. Am. J. Med. Genet. B. Neuropsychiatr. Genet., 2016, vol. 171, pp. 1032-1040.

19. Shi H., Tan S.-J., Zhong H., Hu W., Levine A., Xiao C.-J., Peng Y., Qi X.B., Shou W.H., Ma R.L., Li Y., Su B., Lu X. Winter temperature and UV are tightly linked to genetic changes in the p53 tumor suppressor pathway in Eastern Asia. Am. J. Hum. Genet., 2009, vol. 84, pp. 534-541.

20. Murdoch J. D., Speed W. C., Pakstis A. J., Heffelfinger C. E., Kidd K. K. Worldwide population variation and haplotype analysis at the serotonin transporter gene SLC6A4 and implications for association studies. Biol. Psychiatry, 2013, vol.74, pp. 879-889.

21. Li M., Luo X.-J., Rietschel M., Lewis C.M., Mattheisen M., Müller-Myhsok B., Jamain S., Leboyer M., Landén M., Thompson P.M., Cichon S., Nöthen M.M., Schulze T.G., Sullivan P.F., Bergen S.E., Donohoe G., Morris D. W., Hargreaves A., Gill M., Corvin A., Hultman C., Toga A. W., Shi L., Lin Q., Shi H., Gan L., Meyer-Lindenberg A., Czamara D., Henry C., Etain B., Bis J.C., Ikram M. A., Fornage M., Debette S., Launer L. J., Seshadri S., Erk S., Walter H., Heinz A., Bellivier F., Stein J. L., Medland S.E., Arias Vasquez A., Hibar D. P., Franke B., Martin N. G., Wright M. J., Su B. Allelic differences between Europeans and Chinese for CREB1 SNPs and their implications in gene expression regulation, hippocampal structure and function, and bipolar disorder susceptibility. Mol. Psychiatry, 2014, vol. 19, pp. 452-461.

22. Luo X.-J., Mattheisen M., Li M., Huang L., Rietschel M., Børglum A. D., Als T. D., van den Oord E. J., Aberg K. A., Mors O., Mortensen P. B., Luo Z., Degenhardt F., Cichon S., Schulze T. G., Nöthen M. M., Su B., Zhao Z., Gan L., Yao Y. G. Systematic Integration of Brain eQTL and GWAS Identifies ZNF323 as a Novel Schizophrenia Risk Gene and Suggests Recent Positive Selection Based on Compensatory Advantage on Pulmonary Function. Schizophr. Bull., 2015, vol. 41, pp. 1294-1308.

23. Henn B. M., Cavalli-Sforza L.L., Feldman M.W. The great human expansion. Proc. Nat. Acad. Sci. USA, 2012, vol. 109, pp. 17758-17764.

24. World Health Organization. The ICD-10 Classification of Mental and Behavioural Disorders: Diagnostic Criteria for Research. Geneva, 1993. 263 p.

25. American Psychiatric Association. Diagnostic and Statistical Manual of Mental Disorders: $5^{\text {th }}$ ed.: DSM5. ManMag, 2003.

26. American Psychiatric Association, American Psychiatric Association. DSM-5 Task Force. American Psychiatric Association: Diagnostic and statistical manual of mental disorders. ${ }^{\text {th }}$ ed. N. Y., 2013.

27. Taylor M. A., Fink M. Catatonia in psychiatric classification: a home of its own. Am. J. Psychiatry, 2003, vol. 160, no. 7, pp. 1233-1241.

28. Pommepuy N., Januel D. Catatonia: resurgence of a concept. A review of the international literature. Encephale, 2002, vol. 28, no. 6 (Pt. 1), pp.481-492.

29. Sanislow C.A., Pine D.S., Quinn K.J., Kozak M.J., Garvey M.A., Heinssen R.K., Wang P.S., Cuthbert B.N. Developing constructs for psychopathology research: research domain criteria. J. Abnorm. Psychol., 2010, vol. 119, pp. 631-639.

30. Doi N., Hoshi Y., Itokawa M., Yoshikawa T., Ichikawa T., Arai M., Usui Ch., Tachikawa H. Paradox of schizophrenia genetics: is a paradigm shift occurring? Behav. Brain Funct., 2012, vol. 8, p. 28.

31. Harrison P. J. Recent genetic findings in schizophrenia and their therapeutic relevance. J. Psychopharmacol., 2015, vol. 29, pp. 85-96. 
32. Carcone D., Ruocco A.C. Six Years of Research on the National Institute of Mental Health's Research Domain Criteria (RDoC) Initiative: A Systematic Review. Front. Cell. Neurosci., 2017, vol. 11, p. 46.

33. Moselhy H., Eapen V., Akawi N. A., Younis A., Salih B., Othman A. R., Yousef S., Clarke R. A., Ali B. R. Secondary association of PDLIM5 with paranoid schizophrenia in Emirati patients. Meta Gene, 2015, vol. 5, pp. 135-139.

34. Forstner A. J., Hecker J., Hofmann A., Maaser A., Reinbold C. S., Mühleisen T. W., Leber M., Strohmaier J., Degenhardt F., Treutlein J., Mattheisen M., Schumacher J., Streit F., Meier S., Herms S., Hoffmann P., Lacour A., Witt S.H., Reif A., Müller-Myhsok B., Lucae S., Maier W., Schwarz M., Vedder H., Kammerer-Ciernioch J., Pfennig A., Bauer M., Hautzinger M., Moebus S., Schenk L.M., Fischer S. B., Sivalingam S., Czerski P. M., Hauser J., Lissowska J., Szeszenia-Dabrowska N., Brennan P., McKay J. D., Wright A., Mitchell P. B., Fullerton J. M., Schofield P. R., Montgomery G. W., Medland S.E., Gordon S. D., Martin N. G., Krasnov V., Chuchalin A., Babadjanova G., Pantelejeva G., Abramova L. I., Tiganov A.S., Polonikov A., Khusnutdinova E., Alda M., Cruceanu C., Rouleau G. A., Turecki G., Laprise C., Rivas F., Mayoral F., Kogevinas M., Grigoroiu-Serbanescu M., Becker T., Schulze T.G., Rietschel M., Cichon S., Fier H., Nöthen M.M. Identification of shared risk loci and pathways for bipolar disorder and schizophrenia. PLoS One, 2017, vol.12, no. 2: e0171595. doi: 10.1371/journal. pone.0171595.

35. Alfimova M. V., Golimbet V.E., Korovaĭtseva G.I., Lezheĭko T.V., Abramova L.I., Aksenova E. V., Bolgov M. I. Vliianie polimorfizma 5-HTTLPR gena perenoschika serotonina na raspoznavanie mimicheski vyrazhaemykh emotsii pri shizofrenii [The effect of the serotonin transporter 5-HTTLPR polymorphism on the recognition of facial emotions in schizophrenia]. Zh. Nevrol. i Psikhiatr. im. S. S. Korsakova, 2014, vol. 114, no. 1, issue 1, pp. 42-48. (In Russian)

36. Kolesnichenko E. V., Baryl'nik Iu. B., Golimbet V.E. Vliianie gena BDNF na fenotipicheskuiu ekspressiiu paranoidnoi shizofrenii [Influence of BDNF gene on phenotypic expression of paranoid schizophrenia]. Social and Clinical Psychiatry, 2015, vol.2, pp.45-49. (In Russian)

37. Schumacher J., Jamra R. A., Becker T., Ohlraun S., Klopp N., Binder E. B., Schulze T. G., Deschner M., Schmäl C., Höfels S., Zobel A., Illig T., Propping P., Holsboer F., Rietschel M., Nöthen M. M., Cichon S. Evidence for a relationship between genetic variants at the brain-derived neurotrophic factor (BDNF) locus and major depression. Biol. Psychiatry, 2005, vol. 58, pp. 307-314.

38. Voineskos A. N., Lerch J. P., Felsky D., Shaikh S., Rajji T. K., Miranda D., Lobaugh N. J., Mulsant B. H., Pollock B. G., Kennedy J. L. The brain-derived neurotrophic factor Val66Met polymorphism and prediction of neural risk for Alzheimer disease. Arch. Gen. Psychiatry, 2011, vol. 68, pp. 198-206.

39. Northoff G. Brain imaging in catatonia: current findings and a pathophysiologic model. CNS Spectr., 2000, vol. 5, pp. 34-46.

40. Rajmohan V., Mohandas E. Neurobiology of catatonia. Health Science, 2013, vol. 2, no. 3, pp. 1-7.

41. Zhilyaeva T. V., Sergeeva A. V., Blagonravova A. S., Akimova E. V., Kasimova L. N. Polimorfizm gena obmena folatov MTHFR677C $>\mathrm{T}$ i katatonicheskaia simptomatika shizofrenii [Folate metabolism genetic polymorphism MTHFR677C>T and catatonic symptoms of schizophrenia]. Neurological Bulletin. Journal named after V.M. Bekhterev, 2016, vol.48, no. 2, pp. 12-16. (In Russian)

42. Kay S. R., Sevy S. Pyramidical model of schizophrenia. Schizophr. Bull., 1990, vol. 16, pp. 537-545.

43. Il'ina N. A., Zakharova N. V. Dlitel'nye remissii diskineticheskogo tipa pri pristupoobraznoi shizofrenii [Long-term dyskinetic remissions in shift-like schizophrenia]. Zh. Nevrol. i Psikhiatr. im. S. S. Korsakova, 2010, vol.110, no. 12, pp.17-23. (In Russian)

44. Costain G., Bassett A.S. Clinical applications of schizophrenia genetics: genetic diagnosis, risk, and counseling in the molecular era. Appl. Clin. Genet., 2012, vol.5, pp.1-18.

45. Sekar A., Bialas A.R., de Rivera H., Davis A., Hammond T.R., Kamitaki N., Tooley K., Presumey J., Baum M., Van Doren V., Genovese G., Rose S. A., Handsaker R. E., Daly M. J., Carroll M. C., Stevens B., McCarroll S. A. Schizophrenia risk from complex variation of complement component 4. Nature, 2016, vol. 530, pp. 177-183.

46. Traylor M., Farrall M., Holliday E. G., Sudlow C., Hopewell J. C., Cheng Y.-C., Fornage M., Ikram M. A., Malik R., Bevan S., Thorsteinsdottir U., Nalls M. A., Longstreth W., Wiggins K. L., Yadav S., Parati E. A., Destefano A. L., Worrall B. B., Kittner S. J., Khan M. S., Reiner A. P., Helgadottir A., Achterberg S., Fernandez-Cadenas I., Abboud S., Schmidt R., Walters M., Chen W. M., Ringelstein E. B., O’Donnell M., Ho W.K., Pera J., Lemmens R., Norrving B., Higgins P., Benn M., Sale M., Kuhlenbäumer G., Doney A.S., Vicente A.M., Delavaran H., Algra A., Davies G., Oliveira S. A., Palmer C.N., Deary I., Schmidt H., Pandolfo M., Montaner J., Carty C., de Bakker P.I., Kostulas K., Ferro J. M., van Zuydam N. R., Valdimarsson E., Nordestgaard B. G., Lindgren A., Thijs V., Slowik A., Saleheen D., Paré G., Berger K., Thorleifsson G., Hofman A., Mosley T.H., Mitchell B.D., Furie K., Clarke R., Levi C., Ses- 
hadri S., Gschwendtner A., Boncoraglio G. B., Sharma P., Bis J. C., Gretarsdottir S., Psaty B. M., Rothwell P. M., Rosand J., Meschia J.F., Stefansson K., Dichgans M., Markus H.S. Genetic risk factors for ischaemic stroke and its subtypes (the METASTROKE collaboration): a meta-analysis of genome-wide association studies. Lancet Neurol., 2012, vol.11, pp.951-962.

47. Gretarsdottir S., Thorleifsson G., Manolescu A., Styrkarsdottir U., Helgadottir A., Gschwendtner A., Kostulas K., Kuhlenbäumer G., Bevan S., Jonsdottir T., Bjarnason H., Saemundsdottir J., Palsson S., Arnar D. O., Holm H., Thorgeirsson G., Valdimarsson E. M., Sveinbjörnsdottir S., Gieger C., Berger K., Wichmann H.E., Hillert J., Markus H., Gulcher J. R., Ringelstein E. B., Kong A., Dichgans M., Gudbjartsson D. F., Thorsteinsdottir U., Stefansson K. Risk variants for atrial fibrillation on chromosome 4q25 associate with ischemic stroke. Ann. Neurol., 2008, vol. 64, pp. 402-409.

48. Gudbjartsson D.F., Holm H., Gretarsdottir S., Thorleifsson G., Walters G.B., Thorgeirsson G., Gulcher J., Mathiesen E. B., Njølstad I., Nyrnes A., Wilsgaard T., Hald E. M., Hveem K., Stoltenberg C., Kucera G., Stubblefield T., Carter S., Roden D., Ng M. C., Baum L., So W.Y., Wong K. S., Chan J.C., Gieger C., Wichmann H.E., Gschwendtner A., Dichgans M., Kuhlenbäumer G., Berger K., Ringelstein E. B., Bevan S., Markus H.S., Kostulas K., Hillert J., Sveinbjörnsdóttir S., Valdimarsson E.M., Løchen M.L., Ma R.C., Darbar D., Kong A., Arnar D. O., Thorsteinsdottir U., Stefansson K. A sequence variant in ZFHX3 on 16q22 associates with atrial fibrillation and ischemic stroke. Nat. Genet., 2009, vol.41, pp. 876-878.

Received: 31.05.2017

Accepted: 22.10.2017

Author's information:

Zakharova Nataliia V. — PhD; nataliza80@gmail.com

Nizamutdinov Igor I. - researcher; igor@genotek.ru

Musatova Veronika V. - researcher; veronika@genotek.ru

Ilinsky Valery V. - CEO of Genotek Ltd.; valery@genotek.ru

Morozova Anna Yu. _ PhD; hakurate77@gmail.com

Bocharova Mariia O. — MSc; mariia.bocharova@kcl.ac.uk

Reznik Aleksandr M. — PhD, Associate Professor; a.m.reznik1969@gmail.com

Kostyuk Georgiy P. — PhD, Professor; kgr@yandex.ru

\section{Перспективы полногеномного поиска ассоциаций расстройств шизофренического спектра}

Н. В.Захарова ${ }^{1,2}$, И. И. Низамутдинов ${ }^{3}$, В. В. Мусатова ${ }^{3}$, В. В. Ильинский $\check{̆}^{3,4}$ А. Ю. Морозова ${ }^{2,5}$, М. О. Бочарова ${ }^{6}$, А. М.Резник

${ }^{1}$ Российский национальный исследовательский медицинский университет им. Н. И. Пирогова, Российская Федерация, 117997, Москва, ул. Островитянова, 1

${ }^{2}$ Психиатрическая клиническая больница № 1 им. Н. А. Алексеева, Российская Федерация, 115191, Москва, Загородное шоссе, 2

${ }^{3}$ ООО «Генотек», Российская Федерация, 105120, Москва, Наставнический пер., 17, стр. 1

${ }^{4}$ НИИ биомедицинской химии им. В.Н. Ореховича, Российская Федерация, 119121, Москва, ул. Погодинская, 10

${ }^{5}$ Национальный медицинский исследовательский центр психиатрии и наркологии им. В.П. Сербского, Российская Федерация, 119991, Москва, Кропоткинский пер., 23

${ }^{6}$ Королевский колледж Лондона, Великобритания, SE5 8AF, Лондон, де Криспиньи Парк, 16

${ }^{7}$ Московский государственный университет пищевых производств, Российская Федерация, 125080, Москва, Волоколамское шоссе, 11

Для цитирования: Zakharova N. V., Nizamutdinov I. I., Musatova V. V., Ilinsky V. V., Morozova A. Yu., Bocharova M. O., Reznik A. M., Kostyuk G.P. Future directions in genome-wide association studies of schizophrenia spectrum disorders // Вестник Санкт-Петербургского университета. Медицина. 2018. Т. 13. Вып. 1. С. 72-82. https://doi.org/10.21638/11701/spbu11.2018.107 
Стремительное развитие диагностических технологий, в частности метода полногеномного поиска ассоциаций, приближает понимание этиопатогенетических основ эндогенных психических заболеваний. Накопленный на современном этапе опыт полногеномных исследований позволяет оценить значимость тех или иных генетических маркеров в развитии указанных заболеваний. Внедрение скрининговых систем, оценка прогноза заболевания остаются вопросом будущего в силу конецептульно-методологических противоречий. В настоящей статье приводится анализ результатов проведенных полногеномных исследований шизофрении и дается обоснование актуальности глубокого фенотипирования расстройств шизофренического спектра с целью уточнения результатов генетических исследований.

Ключевые слова: шизофрения, генетический маркер, однонуклеотидный полиморфизм, полногеномное исследование, фенотипирование. 